\title{
EDITORAufmg
}

\section{Primeira Parte - Do sertão ao território: Ocupação e políticas do espaço nas Minas Gerais}

Cláudia Damasceno Fonseca

\section{SciELO Books / SciELO Livros / SciELO Libros}

FONSECA, C.D. Do sertão ao território: Ocupação e políticas do espaço nas Minas Gerais. In: Arraiais e vilas d'el rei: espaço e poder nas Minas setecentistas [online]. Belo Horizonte: Editora UFMG, 2011. Humanitas series, pp. 47-50. ISBN: 978-85-423-0307-0. https://doi.org/10.7476/9788542303070.0004.

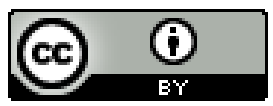

All the contents of this work, except where otherwise noted, is licensed under a Creative Commons Attribution 4.0 International license.

Todo o conteúdo deste trabalho, exceto quando houver ressalva, é publicado sob a licença Creative Commons Atribição 4.0.

Todo el contenido de esta obra, excepto donde se indique lo contrario, está bajo licencia de la licencia Creative Commons Reconocimento 4.0. 
Primeira Parte

DO SERTÃO AO TERRITÓRIO

OCUPAÇÃO E POLÍTICAS DO ESPAÇO

NAS MINAS GERAIS 
"(...) sertão dos Cataguases, nome que nos primeiros anos tiveram, chamadas Minas Gerais pela extensão das que depois lhes foram descobrindo, a que também pelo tempo adiante se lhes foi acomodando o nome do sítio do seu descobrimento".

"E fizeram arraiais onde achavam melhores conveniências, que alguns hoje são vilas (...)."

"A este pois espaçoso e dilatado continente (...) quis a Divina Providência, além das preciosidades que produz, enriquecer não só com minas de topázios, diamantes e pedras preciosas mas de ouro, que por espaço de quinhentas léguas, quase em quadro, se está extraindo em muitas partes, cuja insaciável fome de todos os mortais obrigou e obriga a tanta gente, que se compõe hoje este vasto país e província de Minas de muitos lugares, vilas, e da cidade de Mariana, com governo eclesiástico, e assim também de militar e político, porque se divide em (...) várias comarcas com ouvidorias e câmaras (...)."

(Trechos de relatos históricos sobre a descoberta das minas, $\mathrm{ca}$. 1750, extraídos do Códice Costa Matoso, p. 197, 276-277)

Durante os séculos XVI e XVII, a exploração e a conquista do interior do Brasil progrediram de forma bastante lenta, refletindo a prioridade dada então pela Coroa portuguesa à ocupação das zonas costeiras. Esse fato pode ser constatado pelo exame de vários exemplares da cartografia antiga da América do Sul. No "Mapa da Terra Firme do Peru, Brasil e País das Amazonas", de Guillaume de l'Isle, de 1716, vemos o quanto era ainda tênue o conhecimento disponível sobre a região centro-sul da colônia. Nesta época, nem mesmo o arguto e minucioso géographe royal da corte de Luis XV havia sido capaz de apresentar mais que 
um esboço das principais bacias hidrográficas, alguns nomes de "nações" indígenas que habitavam o interior do continente, além de vagas referências a lugares lendários, que constituíam o foco de expedições em busca de pedras e metais preciosos.

Quarenta anos depois, o progresso é notável: o mapa da "América Meridional desenhado a partir das memórias mais recentes dos Melhores Geógrafos", publicado em Amsterdã no ano de 1757, assinala numerosos rios e serras, bem como algumas vilas instituídas pela Coroa no interior da colônia. Em outra escala, os mapas do militar português José Joaquim da Rocha, desenhados por volta de 1770, mostram de forma bastante detalhada a vasta rede hidrográfica da capitania de Minas Gerais e identificam um número impressionante de povoações e de fazendas disseminadas sobre essas terras, que haviam se tornado a mais preciosa conquista portuguesa.

Como se sabe, a exploração e o povoamento do vasto sertão que, pouco a pouco, veio a constituir as Minas Gerais foram, sobretudo, obras de particulares. No entanto, este caráter dito "espontâneo" do povoamento não significou uma ausência do poder metropolitano na região. Por um lado, a Coroa apoiou várias iniciativas de colonos que, por conta própria, investiram na prospecção de riquezas e na ocupação do interior da colônia - o sertão. Por outro lado - e é esse o aspecto que desejaríamos sublinhar -, o desenvolvimento subsequente das povoações fundadas pelos pioneiros esteve sempre condicionado pelas funções, pelo estatuto e pelos títulos que foram atribuídos a estes núcleos pelo rei de Portugal e por seus representantes.

A primeira parte do presente estudo dedica-se a uma análise diacrônica do processo de povoamento e de territorialização dos sertões mineiros. O objetivo é identificar as modalidades e os ritmos de formação dos estabelecimentos humanos, bem como as questões envolvidas na constituição da malha administrativa da capitania. Trata-se, pois, de estudar o processo de formação das suas circunscrições civis (comarcas, concelhos, julgados) e eclesiásticas (freguesias, dioceses) e de analisar como se deu a escolha das respectivas sedes. Este processo será abordado numa escala que permite abranger toda a capitania e relacionado ao contexto econômico, social e político específico das Minas Gerais. Desta forma, será possível avaliar em que medida as diretivas 
metropolitanas e, notadamente, o sistema fiscal vigente nas Minas influíram na formação de sua malha político-administrativa e na definição dos limites da capitania.

A ocupação das terras e a constituição de centros do poder local em alguns povoados alteram não somente o estatuto destes últimos - que são promovidos a vilas, cidades, sedes de paróquias etc. -, mas transformam também as zonas circundantes, que passam a ser consideradas como territórios submetidos às povoações-sede. No momento das primeiras descobertas auríferas, tratava-se de matas e campos quase desertos, pois a ação dos bandeirantes já havia feito com que a maior parte das populações autóctones se refugiasse nas zonas periféricas da futura capitania (principalmente no Vale do Rio Doce e zonas oeste e nordeste). À medida que iam surgindo povoados mineradores e zonas rurais, estas terras transformavam-se em territórios nomeados, cartografados e submetidos ao controle de diversas instâncias de poder.

Pouco a pouco, a região mineradora foi perdendo sua denominação original, afastando-se progressivamente da categoria de sertão. Esta transformação refletia-se nas sucessivas denominações de cada porção de terra que começava a ser ocupada. De fato, os contemporâneos utilizavam um vocabulário variado para nomear as novas zonas exploradas e os núcleos de povoamento da capitania: sertão, conquista, campanha, continente, distrito, arraial, aplicação etc. Trata-se de termos genéricos que designam diferentes tipos de ocupação, bem como graus variados de organização e de institucionalização dos espaços. Reveladores das categorias, das escalas e dos estágios da colonização, estes termos constituem uma série de conceitos espaciais que requerem uma análise. 